\title{
MOTHERS AND NON-MOTHERS IN THE LABOR MARIKET: MEXICAN REGULATIONS VS. THE ILO MATERNITY PROTECTION CONVENTION, 2000 (NO. 183)
}

Prof. Dr. Barbara Stępień ${ }^{*}$

UDK: $349.2: 331.817(725.1)$

349.2-055.2(725.1)

341.241:349.2-055.2(725.1)

DOI: 10.3935/zpfz.71.1.03

Pregledni znanstveni rad

Primljeno: ožujak 2021.

This article aims to analyze the social and legal situation of women in the labor market, especially in relation to the impact which maternity status impresses upon this. The author intends to explain why women are discriminated in the labor market (notably once they become mothers) by applying current psychological and economic theories on discrimination. Furthermore, the International and Mexican legal frameworks on the prohibition of discrimination and maternity protection are herein discussed and analyzed. Finally, the author proposes introducing and developing paternity labor rights as a necessary condition to eradicate gender discrimination in the labor market.

Keywords: gender; discrimination; pay gap; maternity; paternity; labor rights

Dr. Barbara Stępień, Professor, Universidad Iberoamericana, Prolongacion Paseo de la Reforma 880, Lomas de Santa Fe, Álvaro Obregón, 01219 Mexico City, Mexico; barbara.stepien@hotmail.com;

ORCID ID: orcid.org/0000-0002-2430-5445 


\section{INTRODUCTORY REFLECTIONS: WALKING ON THE MOON}

At 2.56 UTC on July 21, 1969, Neil Armstrong, as the first person to ever set foot on the Moon, said that it was "[...] one small step for man, one giant leap for mankind [...]" - this sentence was to herald the beginning of a multitude of greater developments to come. Nonetheless, even though over the following fifty years human beings have kept on rapidly progressing - exploring outer space, virtually connecting the whole world to the Internet, successfully transplanting almost all human organs, and continuously developing artificial intelligence - women still suffer gender discrimination in the labor market, and their professional position diminishes even more once they become mothers.

According to various statistical reports on gender discrimination, working opportunities, and professional development, women still need to choose between a professional or family life in most countries, and the possibility of achieving a sustainable work-life balance ${ }^{1}$ remains very distant. The average pay gap registered between men and women in the Organization for Economic Co-operation and Development (OECD) member states is on the level of $14 \%$ (2018), and, moreover, women form only $23 \%$ of company boards. ${ }^{2}$ The UN Women indicates that, on average, women earn 77 cents for every dollar earned by men, and the difference in lifetime incomes results in that more women than men retire into poverty. ${ }^{3}$ Furthermore, statistical research shows that an additional factor boosting the gender pay gap and labor discrimination is maternity (which surprisingly includes a pay gap between mothers and non-mothers). ${ }^{4}$

Therefore, the objective of this article is to analyze the social and legal situation of women in the labor market, especially in relation to the impact which maternity status impresses upon this. The conducted analysis focuses on one of the largest Latin American countries - Mexico - and the maternity

1 The concept of work-life balance is understood as the possibility (degree) of achieving temporal, behavioral, and emotional equilibrium related to professional work and family needs. Hill, E.; Hawkins, A.; Ferris, M.; Weitzman M., Finding an Extra Day a Week: The Positive Influence of Perceived Job Flexibility on Work and Family Life Balance, Family Relations, vol. 50, no. 1, 2001, p. 49. On the topic see also Półtorak, M., Projekt Dyrektywy WLB-Nowe podejście do równości ptci w zatrudnieniu?, Studia z Zakresu Prawa Pracy i Polityki Społecznej, no. 4, 2019, pp. 317-339.

2 The Economist, The glass-ceiling index, 2019, https://econ.st/2NwlzIv (30/03/2020).

3 UN Women, Equal pay for work of equal value, https://bit.ly/2Y5BbqW (01/04/2020).

4 For example, according to the UN Women, a $21 \%$ pay gap exists between women with and without children in the Asia region and a 27\% pay gap exists between the aforementioned categories of women in Sub-Saharan Africa. Ibid. 
protection provided therein. Thus, in the first part of this article, statistical data regarding Mexican women (mothers and non-mothers) concerning their civil status, professional activeness, education level, and type of work are presented. Furthermore, current psychological and economic theories on discrimination are analyzed to answer the question why women are discriminated in the labor market (notably once they become mothers). Moreover, Mexican regulations on the prohibition of discrimination and maternity protection are reviewed in the light of the international legal framework (especially the ILO instruments such as the Maternity Protection Convention, no. 183, of 2000). The conducted studies aim to verify the hypothesis that the introduction and development of paternity labor rights constitute a necessary condition to eradicate gender discrimination in the labor market. In conclusion, the amendments required in the Mexican legal framework are presented.

\section{THE MEXICAN REALM OF PRODUCTIVE AND REPRODUCTIVE WORK}

\section{a) Mexican mothers and non-mothers in numbers}

For the conducted analysis, it is necessary to present a panorama of Mexican women (mothers and non-mothers) considering such factors as: civil status, education level, type of work, and associated pay discrepancies.

According to the National Survey of Occupation and Employment (Encuesta Nacional de Ocupación y Empleo) of the National Institute of Statistics and Geography - NISG - (Instituto Nacional de Estadística y Geografía), 73.3\% of women in Mexico have been mothers ${ }^{5}$ (specifically 35.2 million out of 48 million women), as of $2017^{6}$

Of the 35.2 million Mexican women who have experienced pregnancy and motherhood, 52.4\% are married, 18.8\% remain in partnership relationships, $10.2 \%$ are widows, $6.6 \%$ are separated, and $2.5 \%$ are divorced. The remaining 9.6\% are single mothers. ${ }^{7}$

Regarding the relationship between marital status and participation in the working market, the data shows that singles mothers are much more profession-

5 The presented data refers to women above 15 years old having children (hereinafter, mothers).

6 The presented data as of the year 2017 are the latest available data for Mexico.

7 Instituto Nacional de las Mujeres, Las madres en cifras, 2018, https://www.gob.mx/ inmujeres/articulos/las-madres-en-cifras (31/12/2020). 
ally active than other mother groups. That is, $69 \%$ of single mothers participate in the labor market, while from the common group of separated, divorced, and widowed mothers $-45 \%$ of them are professionally active. In the case of married women or those remaining in relationships, this figure is $38.6 \%$.

While viewing Mexican mothers from the perspective of their education level, the data is quite alarming; that is, $41.4 \%$ have not finished basic education (in comparison, only $20.5 \%$ of non-mothers have not completed basic education). Regarding secondary and tertiary education, only $23.9 \%$ of mothers completed this educational level compared to $42.5 \%$ of non-mothers. ${ }^{8}$

There is also an inversely proportional relationship between the number of children and the mother's participation in the working market (the higher the number of children, the lower the presence). That is, $49.6 \%$ of mothers who have between 1 and 2 children are active on the labor market in comparison to $41.4 \%$ of mothers who have between 3 and 5 children, whilst only $22.7 \%$ of those with more than 6 children are actually professionally active.?

The majority of Mexican mothers (64\%) work as subordinate and paid workers, $26.6 \%$ of them are self-employed, $6.6 \%$ work without any remuneration, and only $2.8 \%$ of mothers are employers themselves. ${ }^{10}$ Finally, $37.8 \%$ of mothers work less than 35 hours weekly (representing a part-time working regime), while only $30.5 \%$ of non-mothers work in this modality. ${ }^{11}$

\section{b) The Mexican pay gap}

According to the National Institute of Women (Instituto Nacional de las Mujeres) in Mexico, the pay gap between women and men varies from $17.7 \%$ up to even $31.9 \%$, depending on their education level, as of $2015 .{ }^{12}$ The largest pay gap exists between two quite the opposite groups of women and men:

$8 \quad$ Ibid.

9 Ibid.

10 Ibid.

11 Ibid.

12 The latest available data are for the year 2015. The presented data refer to working persons above 15 years old as this is the minimum working age as permitted by the labor law regulations in Mexico (Article 5, para I of the Federal Labor Law). The presented data pertain to persons working more than 30 hours per week. Thus, it excludes any part-time working persons (which, in the majority, are women). Such an approach enables obtaining more homogeneous and objective results. Instituto Nacional de las Mujeres, Brecha salarial de género en México, Año 2016-II, Mexico City, 2016, p. 11 (the full report may be consulted at: https://bit.ly/2Lnduaq, 05/01/2021). 
those without any basic education (gender pay gap of 30.7\%) and those having attained a professional degree (31.9\%). ${ }^{13}$ The lowest gender salary gap appears between persons not having completed primary school (17.7\%) and persons who completed technical education - not gaining a university degree (19.4\%).

On the other hand, the Mexican Institute for Competitiveness (Instituto Mexicano para la Competitividad) indicated that between the period of 2017 and the first trimester of 2020 (before the beginning of the economic crisis caused by the breakout of the COVID-19 pandemic), a Mexican woman was earning, on average, 85 pesos for every 100 pesos earned by a man (an average salary gap of $15 \%) .^{14}$

\section{WHY DO WE DISCRIMINATE WOMEN IN THE LABOR MARKET?}

The presented statistical data pertaining to the position of women in the labor market, both in the world and Mexico, clearly show that universally women do not enjoy the same rights and do not have the same equal opportunities as men. Therefore, a pertinent question arises, why do we disfavor women in the labor market compared to men?

The answer may be found in the phenomena inseparably linked with labor since the beginning of humanity; this is in working discrimination. Like any type of discrimination, labor discrimination means the differentiation of individual workers (or groups) due to various grounds such as race, color, religion, identity, gender, etc. ${ }^{15}$ Moreover, it is also a very complex phenomenon which is caused by - and causes - a full package of conducts. There are currently two basic theories on discrimination that try to explain this: a psychological and an economic one.

\section{a) The psychological theory on discrimination}

To analyze the psychological theory on discrimination, it is important to mention two strongly related phenomena which social psychologists often

13 Ibid, p. 14.

14 Instituto Mexicano para la Competitividad, Las mujeres no ganan lo mismo que los hombres. Análisis de la brecha salarial en México, Mexico City, 2020, p. 3 (the full report may be consulted at: https://bit.ly/2L87Lp7, 05/01/2020).

15 Rzecznik Praw Obywatelskich, Przeciw dyskryminacji: Poradnik RPO, Biuro Rzecznika Praw Obywatelskich, Warszawa, 2013, p. 7. 
underline while discussing discrimination; namely prejudice and stereotypes. Even though these three words (discrimination, stereotypes, and prejudice) sound very familiar, is it really clear what they mean? Very often, they are employed interchangeably - although it must be noted - they are not synonyms.

A stereotype is a conviction concerning certain characteristics of a group of people (which often constitutes an overgeneralization and is inaccurate) and which is very difficult to change even if the person applying the stereotype receives new information. ${ }^{16}$ On the other hand, prejudice is an "unjustifiable negative attitude" expressed by someone towards a concrete group of people or its individual members. ${ }^{17}$ While prejudice is an "attitude", discrimination can be defined as an "unjustifiable negative behavior" towards a member of a category (a group of people sharing certain characteristics) without any "deservingness" or "reciprocity". ${ }^{18}$ In other words, an act of discrimination requires two components: thinking (judging) and acting (behaving). Seeing discrimination from its victim's perspective, the only reason a person suffers discrimination is due to belonging to a certain category of people, and there is no other "deservingness". This "deservingness" is the key word in understanding and "explaining" the conduct of the perpetrator (the person discriminating others). Due to historical and social norms, a perpetrator's behavior is often not perceived as anything negative, neither by the perpetrator nor by other people, and it seems to be "justified". ${ }^{19}$ Certainly, the persons suffering discrimination will see this situation differently, but even they themselves may sometimes find the treatment they suffered "justified" due to their concrete characteristics. ${ }^{20}$ Finally, discrimination may be reflected in lots of different types of direct and indirect conduct. It can be committed in a conscious or unconscious (automatic) way and be expressed verbally or not. Thus, it may result in avoiding contact or

16 Al Ramiah, A.; Hewstone, M.; Dovidio, J. F.; Pennerp, L. A, The Social Psychology of Discrimination: Theory, Measurement, and Consequences, in: Russell, H.; Bond, L.; McGinnity, F. (eds.), Making equality count: Irish and international approaches to measuring discrimination, Liffey Press, Dublin, 2010, pp. 84-85.

17 Ibid., p. 84.

18 Correll, J.; Judd, C. M.; Park, B.; Wittenbrink, B., Measuring prejudice, stereotypes and discrimination, in: Dovidio, J. F.; Hewstone, M.; Glick, P.; Esses, V. M. (eds.), The Sage Handbook of Prejudice, Stereotyping, and Discrimination, SAGE Publications Ltd., London, 2010, p. 46.

19 Al Ramiah et al., op. cit. (fn. 16), p. 85.

20 In many cases, victims of other types of abuse such as intra-family violence, sexual abuse, etc., also think that they "deserve" it. 
intentionally searching for an aggressive encounter, a denial of opportunities, access, or equal treatment. ${ }^{21}$

\section{b) The economic theory on discrimination}

The other approach to studies on discrimination is the economic theory on discrimination. Arrow (awarded the Nobel Prize in Economics) defined labor discrimination as "the valuation in the marketplace of personal characteristics of the worker that are unrelated to worker productivity". ${ }^{22}$ According to other authors, discrimination can also be understood as a "disadvantage", which consequently transforms itself into an "injustice". ${ }^{23}$

In the current economic literature, the main discrimination theory is based on the statistical discrimination models ${ }^{24}$, which were initially developed by Arrow and Phelps. ${ }^{25}$ According to these, employers make decisions related to human resources (mainly employment-related) based on the limited, statistical information they possess concerning the category (group) to which the candidate belongs. Such conduct derives from the fact that they lack sufficient information on the candidate's productivity. Consequently, the more imperfect the employer's information regarding the candidate/worker, the greater the weight of the judgment of a person's competence is based on the group's behavior to which the

${ }^{21}$ Al Ramiah et al., op. cit. (fn. 16), p. 85.

22 Arrow, K., The Theory of Discrimination, in: Aschenfelter, O.; Rees, A. (eds.), Discrimination in Labor Markets, Princeton University Press, Princeton, 1973, pp. 3-33.

23 Radcliffe Richards, J.; Lucas, J. R., Discrimination, Proceedings of the Aristotelian Society, Supplementary Volumes, vol. 59, Oxford University Press, 1985, pp. 53-83.

24 Since the XX century, there have been two main currents in the economic doctrine regarding discrimination. One of the main works on discrimination in the neoclassical economy was Gary Backer's theory on the "taste-based discrimination models", which was published in the book "The economics of discrimination" (1957). According to Becker's theory, discrimination in working places is caused solely due to the specific tastes (preferences) of employers, co-workers, and customers and is not related to an employee's productivity. Moreover, in a vast range of cases, it is even costly for employers. On the other hand, the Arrow and Phelps models were based on the "rational optimizing behavior and limited information", known as statistical discrimination (analyzed in the paragraph above). Guryan, J.; Charles, K. K., Taste-Based or Statistical Discrimination: The Economics of Discrimination Returns to its Roots, The Economic Journal, vol. 123, no. 572, 2013, pp. F417-F418.

25 Phelps, E. S., The Statistical Theory of Racism and Sexism, American Economic Review, vol. 62, 1972, pp. 659-661. 
candidate "belongs". ${ }^{26}$ In other words, the less reliable information concerning the individual candidate/worker the employer has, the more "important" is what he knows about the entire group.

In current times, many people have become more progressive and consider themselves "equalitarian". They manage to fight against prejudice, stereotypes, and "psychological" discrimination in their own way of thinking. However, when it comes to employment, they often unconsciously "apply" statistical discrimination. In such a way, many women (mothers and non-mothers) suffer statistical discrimination by the sole fact of belonging to a group which traditionally is considered less productive and less devoted to work due to maternity or the possibility of future motherhood. In the case of statistical discrimination, a woman (mother) needs to get the chance to prove that she does not share the characteristics of the group to which she may be categorized. However, to prove it, she needs to be employed first and then obtain equal opportunities for professional development. And here the paradox begins.

\section{WHY DO WE DISCRIMINATE SOME WOMEN MORE THAN OTHERS?}

As demonstrated by the presented statistical data, women are victims of discrimination in the workplace, which in most situations is reflected in a substantial pay gap in comparison to men. One of the main reasons for such a situation is that women sooner or later become mothers, which, according to the aforementioned psychological and economic theories, simply "stigmatizes" them as a "worse" type of worker. Bearing in mind the theoretical (psychological and economic) framework explaining these phenomena, it is necessary to answer the following question: do we discriminate all women equally? As, in this article, the situation of women in the labor market has been studied; it is important to mention that the analyzed group (women) may be divided into several subcategories according to their reproductive stage, that is: 1) pregnant women; 2) mothers; 3) non-mothers. Furthermore, the first category can be divided into: i) women in early pregnancy (not visible); and ii) women in advanced pregnancy (visible). The second subcategory, mothers, can be further subdivided, taking into account whether they are: i) single mothers; or ii) mothers in a relationship (married, partnership, etc.).

Therefore, it must be realized that a woman's situation changes once she becomes a mother, and it varies depending on the stage of motherhood (i.e.,

26 Guryan, Charles, op. cit. (fn. 24), p. F418. 
during pregnancy and childbirth - prenatal and postnatal). The studies show that women - namely mothers, suffer a much greater degree of discrimination and inequality than non-mothers (childless women), and, additionally, they suffer several concrete phenomena: a mommy track, a motherhood penalty, the maternal wall, and, finally, a glass ceiling, which are directly related to their reproductive stage (as explained above).

\section{a) Mommy track}

The term "mommy track" means that a woman chooses to be a mother as a priority, which in consequence delimitates the full path of her life (especially in terms of working conditions such as flexible working arrangements over career development). This term was used for the first time by Jennifer A. Kingson, an American journalist, who wrote an article about this issue for the New York Times Magazine in $1988^{27}$ (this concept was further discussed the following year - 1989 - by Felice Schwartz in her article in the Harvard Business Journal ${ }^{28}$ ).

\section{b) Motherhood penalty}

A motherhood penalty, as its name indicates, is simply a penalty for being a mother. Maternity constitutes an additional "reason" for discrimination (other than "just" being a woman). The "deserved" penalty is reflected mainly in much lower salaries than men or non-mothers. The various studies conducted worldwide indicate that an average motherhood penalty may even vary up to several percent of the wage gap. For example, in the US, mothers suffer around 5\% motherhood penalty per child, and the pay gap between mothers and non-mothers in a group of women under 35 years old is larger than between men and women. Moreover, the motherhood penalty has a financial scope (resulting in lower salaries and a larger pay gap) and the general assessment of the professionalism of a woman. According to studies, mothers are in general

27 Kingson, J. A., Women in the Law Say Path Is Limited by 'Mommy Track', The New York Times, August 8, 1988, Section A, p. 1 (https://nyti.ms/2MfMtpR, 01/01/2021).

28 Schwartz, F., Management Women and the New Facts of Life, Harvard Business Review, January 1, 1989 (https://bit.ly/3alDi4w, 02/01/2021); Eisner, S. P., The Mommy Trek? Working Women's Choices, Journal of Diversity Management, vol. 2, no. 1, 2007, pp. 1-16. For the mother track among teenagers and adolescence see: Stewart, J., The Mommy Track: The Consequences of Gender Ideology and Aspirations on Age at First Motherhood, Journal of Sociology \& Social Welfare, vol. 30, no. 2, 2003, pp. 3-30. 
perceived as less competent than men or non-mothers. At an even greater disadvantage are visibly pregnant women (assessed as even worse employees than non-visibly pregnant women or mothers). It is also worth noticing that such a parenthood penalty does not exist in the case of men, who are rather assessed positively when they become parents. ${ }^{29}$

\section{c) Maternal wall}

Statistically, sooner or later, every woman hits a maternal wall (also known as family responsibilities discrimination) due to her pregnancy (past, present, or future) and maternity. The first major maternal wall case before the US Supreme Court was Phillips v. Martin Marietta Corp., in 1971, where it was ruled that an employer may not refuse to hire a woman with a child at pre-school age (unless it is justified in business terms), if, for the same position, a man with children in this age group is hired. ${ }^{30}$

\section{d) Glass ceiling}

The glass ceiling is a phenomenon closely related to the maternal wall and means that, at a certain moment, women (and other discriminated groups) cannot grow professionally due to their gender and/or maternity. ${ }^{31}$

\section{THE INTERNATIONAL LEGAL FRAMEWORK ON GENDER EQUALITY}

For many years, the international community has been striving relentlessly to equalize men and women's positions in all spheres of human activities. Therefore, throughout the XX century, several international conventions at

29 Correll, Sh. J.; Benard, S.; Paik, I., Getting a Job: Is There a Motherhood Penalty?, American Journal of Sociology, vol. 112, no. 5, 2007, pp. 1297-1298. Similar, Budig, M.; Misra, J.; Boeckmann, I., The Motherhood Penalty in Cross-National Perspective: The Importance of Work-Family Policies and Cultural Attitudes, Social Politics, vol. 19, no. 2, 2012, p. 186.

30 The full ruling is available at: https://bit.ly/3pg9ZS8, 06/02/2021.

31 For further analyses regarding the glass ceiling, see Adams, R.; Funk, P., Beyond the Glass Ceiling: Does Gender Matter?, Management Science, vol. 58, no. 2, p. 229; Bertrand, M., The Glass Ceiling, Becker Friedman Institute for Economics at the University of Chicago, Working Paper, No. 38, 2018, pp. 1-36. 
both international and regional levels were adopted, aimed at eradicating gender discrimination and improving women's positions in various areas, including in the labor market.

Labor discrimination, as discrimination of any kind, is strictly related to a lack of equality between human beings, and one of the main ways to prevent this and eradicate it is to establish concrete legal mechanisms targeting it. At the international level, the first document recognizing the equal position of men and women was the Universal Declaration of Human Rights (UDHR), adopted in 1948. ${ }^{32}$ Almost twenty years later, provisions explicitly prohibiting any form of discrimination were included in the Covenant on Economic, Social, and Cultural Rights $^{33}$ and in the Covenant on Civil and Political Rights ${ }^{34}$ (both from 1966). In 1979, the United Nations General Assembly adopted the "Women's Bill of Rights", the Convention on the Elimination of All Forms of Discrimination against Women (CEDAW), which not only was entirely addressed to women and strictly prohibited any form of their discrimination ${ }^{35}$ but also introduced maternity protection. ${ }^{36}$

32 Article 1 of the UDHR states that all human beings are born equal in their dignity and rights. It must be noted that during the works on the text of the Declaration different wordings were proposed (initially, it was "all men", consequently "all people", and finally "all human beings"). The employment of the final, gender-neutral wording "all human beings" was used thanks to the involvement of Eleanor Roosevelt and the Commission on the Status of Women. Lindbolm, T., Article 1, in: Alfredsson, G.; Eide, A. (eds.), The Universal Declaration of Human Rights: A Common Standard of Achievement, Martinus Nijhoff Publishers, The Hague/Boston/London, 1999 , p. 45.

33 Article 2 of the Covenant on Economic, Social and Cultural Rights, 1966. Moreover, in article 10 para 2 of the Covenant maternity protection was also included.

34 Article 3 of the Covenant on Civil and Political Rights, 1966. Moreover, according to article 23, States Parties "shall take appropriate steps to ensure equality of rights and responsibilities of spouses as to marriage, during marriage and at its dissolution. In the case of dissolution, provision shall be made for the necessary protection of any children".

35 Article 1 of the CEDAW defines discrimination as "any distinction, exclusion or restriction made on the basis of sex which has the effect or purpose of impairing or nullifying the recognition, enjoyment or exercise by women, irrespective of their marital status, on a basis of equality of men and women, of human rights and fundamental freedoms in the political, economic, social, cultural, civil or any other field".

36 Article 11 para 2.b. of the CEDAW. 


\section{THE ILO MATERNITY PROTECTION CONVENTION 2000 (NO. 183)}

In the meantime, in line with the adoption of the above-mentioned documents, the International Labor Organization (ILO) has been making great progress in the development of the conventions improving the position of women in the labor market and providing them with the necessary protection. ${ }^{37}$ The ILO's Maternity Protection Convention, 2000 (MPC 2000) ${ }^{38}$ is the main international legal instrument establishing maternity protection at work adopted in recent years. It aims to provide labor protection to mothers due to their contribution to society (by having children). The MPC 2000 regulates seven key elements (such as scope, leave, benefits, health and employment protection, nondiscrimination, breastfeeding breaks, and facilities). It also establishes the minimum standards and mechanisms to be employed at the national level to provide minimum maternity protection at work.

\section{a) Scope of application of the MPC 2000}

Analyzing the initial provisions of the MPC 2000 and its scope of application (article 2), it may be realized that even though the MPC 2000 seems to cover all women in all sectors of the economy (para 1), its States Parties enjoy a significant margin of discretional power to decide to which categories of workers it should apply. In some cases, such a construction of the MPC's provisions can make it rather exclusive (as opposed to inclusive) and de facto narrows its

37 Among the ILO's "key gender equality conventions", the following conventions may be enumerated: the Equal Remuneration Convention, 1951 (No. 100), the Convention concerning Discrimination in Respect of Employment and Occupation, 1958 (No. 101), the Workers with Family Responsibilities Convention, 1981 (No. 156), the Maternity Protection Convention, 2000 (No. 183). The ILO adopted the first convention on maternity in 1919 (No. 3), which was revised twice: in 1952 by Convention No. 103, and in 2000 by Convention No. 183. Lambert, C., Reproducing Discrimination: Promoting the Equal Sharing of Caring Work in CEDAW, at the ILO and in the SDA, in: Thornton, M. (ed.), Sex Discrimination in Uncertain Times, Australian National University, Canberra, 2010, p. 156.

38 The Maternity Protection Convention (No. 183) was adopted in 2000 and entered into force in 2002 after the required number of ratifications. As of 23/01/2021, a total number of 38 countries have ratified it. Mexico has not signed the convention to date (https://www.ilo.org/dyn/normlex/en/f?p=1000:11300:0::NO:11300:P11300_ INSTRUMENT_ID:312328, 26/02/2021). 
application scope instead of broadening it. ${ }^{39}$ Consequently, it is very common that only women formally contracted in an official (formal) sector may benefit from such protection, as previously mentioned, at the national level. ${ }^{40}$ Thus, in many sectors of the economy (such as the private or informal sector, including independent workers), women are excluded from maternity protection as guaranteed by the MPC 2000 (even though the MPC 2000 does not state it explicitly). Moreover, it also frequently happens that states introduce several additional requirements, which women must fulfill to be able to benefit from the existing protection (for example, a full-time working scheme, a minimum period of employment, a permanent type of contract, or contribution to benefit funds, etc. $\left.{ }^{41}\right)$. Thus, one of the main criticisms of the MPC 2000 is related to its scope of application. Many authors observe that it should be broadened in such a way as to guarantee all the informal categories of female workers mandatory maternity protection (including, for example, rural women ${ }^{42}$ ). It must be remembered that in many countries informal work constitutes a considerably high percentage of the total working population (in the case of Mexico, the informal workforce equaled $56.9 \%$ in $2019^{43}$ ); therefore, this problem requires full international and national attention.

39 Although it must be noticed that the scope of the Maternity Protection Convention, 2000 (No. 183) is wider than of the previous maternity conventions No. 3 and No. 103 (as mentioned above). Vogel, L., ILO New Maternity Convention (2000), Women, Work and Health, 2000, p. 9.

40 For example, in South Africa, only women employed in the formal sector enjoy maternity protection as derived from the ILO Social Security Convention, 1952 (No. 102) and the national statutory measures. Boswell, R.; Boswell, B., Motherhood deterred: Access to maternity benefits in South Africa, Agenda: Empowering Women for Gender Equity, no. 82, 2009, p. 79.

41 In some particular cases, maternity protection may even only be assigned depending on the child's citizenship. For example, in Singapore the duration of maternity leave changes depending on whether a newborn is a citizen of Singapore or not, according to the Child Development Co-Savings Act, Chapter 38a (original enactment: Act no. 13 of 2001, revised edition as of 31 st July 2002) and Employment Act, Chapter 91 (original enactment: act 17 of 1968, revised edition as of 31 ${ }^{\text {st }}$ July 2009).

42 Partially this problem was addressed by the ILO Safety and Health in Agriculture Convention (No. 184), wherein article 18 stated that it also required introducing necessary measures to address the special needs of rural women working in agriculture in terms of their pregnancies, breastfeeding, and reproductive health.

43 Instituto Nacional de Estadística y Geografía, "Resultados de la Encuesta Nacional de Ocupación y Empleo Cifras Durante el Primer Trimestre de 2019”, Mexico City, 2019, p. 1 (the full report available at: https://bit.ly/2NFsdif, 26/01/2021). 


\section{b) Maternity leave provisions}

Further analyzing the provisions of the MPC 2000, maternity leave may be seen as the main mechanism which intends to guarantee necessary protection for women before and after childbirth. According to article 4 of the MPC 2000, women, to which the Convention applies, are entitled to a maternity leave of a minimum of 14 weeks $^{44}$ (including a recommendation according to which a woman should enjoy the right to at least 6 weeks compulsory leave after childbirth $^{45}$ ). Additionally, a woman has the right to medical care during pregnancy, confinement, and recovery from the pregnancy (as indicated in article 6 of the MPC 2000). And finally, mothers and their babies should also be protected from hazardous conditions in the workplace (article 3 of the MPC 2000).

\section{c) Prohibition of discrimination}

The Maternity Protection Convention 2000 prohibits any forms of discrimination of women due to pregnancy or breastfeeding. The convention's provisions guarantee every woman the right to regain her position after returning from maternity or medical leave (pregnancy-related). In other words, this means that a woman should receive the same salary and a similar level of responsibility and duties (the same or an equivalent position, according to article 8, para 2). The MPC 2000 also obliges States Parties to undertake necessary measures in order to guarantee that the pregnancy does not constitute a source of discrimination (article 9). Therefore, the aforementioned provisions cover pregnant women and those who may become pregnant in the near future (for example, childless women or women of child-bearing age). Consequently, it is prohibited to conditionate women's employment from, for example, a negative pregnancy test or proof of sterilization (national laws should also consider these aspects connected with women's reproductive protection). It must be realized that a lack of appropriate provisions covering the above-mentioned aspects puts mothers and breastfeeding women in a worse position than non-mothers (breastfeeding women could even

44 The length of the maternity leave varies across the countries between 8 weeks up to even 1 year. The additional 2 weeks of maternity leave were added to the MPC 2000 (No. 183) in comparison with the Maternity Protection Convention, 1952 (No. 103), where women were granted a minimum period of 12 weeks maternity leave (article 3, MPC, 1952, No. 103).

45 Unless the national legislator decided otherwise after consultations with representative organizations of employers and workers (article 4 para 4 of the MPC 2000). 
be discouraged in such a way to breastfeed, which is considered as a crucial activity both for a woman and a child $\left.{ }^{46}\right)$.

\section{VII.THE MEXICAN LEGAL FRAMEWORK}

Maternity protection is regulated differently depending on the country, starting from fully paid maternity leave through partially paid to completely unpaid. The main purpose of the paid maternal leave is to guarantee a woman and her family financial stability, as the lack of income normally generated by a woman may have severe effects on the household. Additionally, the impact of maternity leave on the woman's career path must also be taken into consideration.

In Mexico, maternity and paternity are guaranteed in article 4 of the Constitution, according to which all persons have the right to decide freely, responsibly, and in an informed manner the number and spacing of the children they wish to have. The legal doctrine underlines that to fulfill the abovementioned guarantee, it is not sufficient not to obstruct the possibility of having children and not to decide on the reproductive rights of the person. However, it is equally important to provide the necessary conditions and measures enabling parenthood (namely, protective mechanisms of equality, prevention of discrimination, to name but a few). Such instruments are specifically derived from labor and health regu-

46 The World Health Assembly in the years 2001-2002 issued a general recommendation for a public health policy, which stipulated that babies should be breastfed exclusively for a minimum period of six months, in total until 2 years old (starting from the sixth month, breastfeeding should be complemented with other food). Moreover, article 10 of the MPC 2000 grants every mother the right to breastfeeding and nursing breaks. It must be remembered that breastfeeding should not be considered a feeding "option", but a final step in the woman's reproductive cycle. According to the MPC 2000, the States Parties should determine in their national legislations the number and length of the nursing/breastfeeding breaks and consider a reduction in working hours per day for breastfeeding women (permitted breaks and/or reduction of working hours should be considered as work and, thus, should be paid accordingly). There are, however, several issues related to the breastfeeding and nursing breaks indicated by national legislators and academics, such as: 1) their number; 2) their frequency and length; 3) the period of time after child birth that a person may take them; 4) their remuneration regime (paid vs unpaid); 4) do they count as "working time"; and 5) may a person lose her income due to them (when, for example, a person is paid by a completed task or is entitled to a bonus based on productivity). Maternity Protection Coalition, Key Elements of Maternity Protection at Work, Maternity Protection Campaign Kit: A Breastfeeding Perspective, 2008, pp. 7-8 (the full document may be consulted at: https://www.waba.org.my/whatwedo/ womenandwork/pdf/ contents.pdf, 26/02/2021). 
lations ${ }^{47}$, which are guaranteed both by the Constitution and secondary laws and at local and federal levels.

\section{a) The Mexican Constitution (Constitución Política de los Estados Unidos Mexicanos)}

The Mexican Constitution grants a package of maternity-related rights to women, which may be found in article 123 letter A para V) of the Constitution, such as:

- pregnant women should not carry out work that requires considerable effort and poses a danger to their health concerning pregnancy;

- they have the right to a six-week-long leave before and a six-week-long leave after delivery;

- during maternity leave, they are entitled to obtain their full salary, maintain their employment and the rights acquired during the employment;

- during the lactation period, they are entitled to two extraordinary breaks per day (30 minutes each) to feed their child/ren.

\section{b) Federal Labor Law (Ley Federal del Trabajo)}

Although the Federal Labor Law establishes labor equality between women and men (in article 164), the existing labor regime's fundamental objective is to protect maternity (article 165). Even though such a construction seems correct at first sight, it must be realized that the Federal Labor Law basically does not grant any paternity labor rights to men (besides the symbolic five working days of paternity leave introduced just a few years ago, in $2012^{48}$ ).

To protect a woman's and newborn's or fetus's health (depending on the developmental stage), both during pregnancy and lactation, it is not allowed to assign a woman to work in unhealthy or dangerous conditions that may generate any risk for her or the baby (article 166). This prohibition includes night shifts (after 10:00 pm) and doing overtime. The protective measures mentioned above should not affect a woman's salary, labor benefits, and other related rights.

47 According to Chapter V of the General Health Law (Ley General de Salud) women enjoy special rights related to maternal health and childcare. According to article 61, maternal healthcare has a priority nature and includes attention during pregnancy, childbirth, and the puerperium.

48 Article 132, part XXVII bis of the Federal Labor Law. 
According to article 170 of the Federal Labor Law, pregnant women and mothers enjoy the following rights:

- during pregnancy, they should not undertake any work-related activities requiring physical effort which may have an impact on the pregnancy or altering their mental health, or generating any danger to their health, such as lifting, pulling, or pushing large weights, standing for a long period of time etc. (article 170.I) ${ }^{49}$;

- a six-week-long leave before and a six-week-long leave after delivery (article 170.III). The specified periods might be prolonged in the case of the inability to work due to the pregnancy or delivery (article 170.III) ${ }^{50}$;

49 According to article 58 of the Federal Regulation on Safety and Health at Work (Reglamento Federal de Seguridad y Salud en el Trabajo) issued based on the Federal Labor Law, as discussed above, it is forbidden to assign pregnant women to such jobs: I. where they are exposed to noise or vibrations that exceed the exposure limits; II. that involve exposure to sources of ionizing and non-ionizing infrared or ultraviolet radiation; III. with abnormal environmental pressures or high or low thermal conditions; IV. that they are exposed to contaminants in the work environment that may affect their health or that of the fetus; V. where toxic, carcinogenic, teratogenic, or mutagenic substances are handled, transported, stored, or processed; VI. where they are exposed to hazardous waste, biological agents, or infectious contagious diseases; VII. that demand moderate and heavy physical effort; loads greater than ten kilograms; forced postures, or with repetitive movements for prolonged periods that imply abdominal or lower limb strain; VIII. of rescue, salvage, and casualty brigades; IX. at height or in confined spaces; X. of welding and cutting; XI. in extreme weather conditions in the open field, which expose them to dehydration, heat stroke, hypothermia, or frostbite; XII. in productive activities in the gas, cement, mining, iron and steel, oil, nuclear and electrical industries; XIII. on drilling towers or offshore platforms; XIV. submarines and subways; and XV. that are established as dangerous or unhealthy in the applicable laws, regulations, and standards. According to article 59 of the analyzed regulation, the employer should temporarily reassign a pregnant woman performing any of the aforementioned types of work to other activities that are not dangerous or unhealthy for her and the fetus. Thus, a woman carrying out her work in any of the referred conditions should inform the employer about her pregnancy immediately after becoming aware of it.

50 The maximum period of four weeks before the due delivery may be transferred to the period after the delivery by an employee's explicit petition. Such a petition must be supported by a medic's written authorization representing the appropriate social security institution or other health institution provided by the employer. To grant the petition, the opinion of the employer and the type of work should be taken into consideration (article 170.II of the Federal Labor Law). 
- during the period of breastfeeding (up to six months), they are entitled to two extraordinary breaks of thirty minutes each per day to feed their child/ren, in a suitable and hygienic place designated by the employer ${ }^{51}$ (article 170. IV) ${ }^{52}$;

- during the aforementioned periods, they have the right to a full salary (in the case of the prolongation of the leave as mentioned before, they have the right to $50 \%$ of their salary during a maximum period of 60 days, article $170 . \mathrm{V})$;

- a return to the position they held before the maternity leave if no more than one year has elapsed from the date of delivery (article 170. VI); and

- inclusion of the pre-and post-natal periods to their seniority (article 170. VII).

As it may be seen, several basic legal mechanisms aiming to grant women maternity protection, which in general comply with the international standards introduced mainly by the ILO, have been developed in Mexico ${ }^{53}$ (regardless of the fact that Mexico has not ratified either of the Maternity Protection Conventions no. 103 nor no. 183). Although, it must be noticed that one of the most important protective measures - maternity leave - is minimal (a twelveweek-long maternity ${ }^{54}$ leave situates Mexico in the group of countries with the

51 If such an arrangement is not possible, the reduction of the working hours by one hour daily may be agreed upon by the employer.

52 According to article 60 of the Federal Regulation on Safety and Health at Work, breastfeeding women should not perform any work where they can be exposed to hazardous chemical substances that could affect the infant's life and health or interrupt the breastfeeding process.

53 The Second Chamber of the Mexican Supreme Court in the ruling CT 422/2016 (and consequently in its biding case-law) stated that working women should be granted a higher standard of protection than other workers. When a working relationship is terminated during a pregnancy there is a reversion of the burden of proof in the judicial trial, that is: the hiring party (patrón) must prove before the court that the employee was not fired because of pregnancy (Gaceta del Semanario Judicial de la Federación, Libro 43, Tomo II, june 2017, p. 1159).

54 The Second Chamber of the Mexican Supreme Court in the ruling AR 955/2019 addressed the case in which the Mexican Institute of Social Security (Instituto Mexicano del Seguro Social) refused to grant maternity leave and payment due to a premature birth. The Institute argued that premature births were not covered by social security and therefore the payment and duration of leave could start being counted from the normal probable dates of birth (the legislation indicated a sixweek-long period before and after childbirth). The Supreme Court concluded that a woman is entitled to a period of twelve weeks and the starting date for calculation 
shortest maternity leaves on a worldwide basis, such as the USA, Botswana, Lesotho, India, or South Africa ${ }^{55}$ ). This de facto impedes a vast selection of women from professional development after childbirth (they need to face the very difficult dilemma of either renouncing their current employment to take care of their newborn or searching for an external caretaker to return to work). Two additional factors heavily contributing to such a situation are: 1) a symbolic paternity leave of five working days, which leaves mothers as de facto the only caretaker of a child/ren ${ }^{56}$ (although this is the average length of paternity leave in Latin America and the Caribbean region ${ }^{57}$ ); and 2) the lack of an institution

is not relevant in such a case. Consequently, the Second Chamber established a binding interpretation of articles 101 of the Social Security Law (Ley del Seguro Social) and 143 of the Regulation of Medical Benefits of the Mexican Institute of Social Security (Reglamento de Prestaciones Médicas del Instituto Mexicano del Seguro Social) enabling such a possibility.

55 Boswell, Boswell, op. cit. (fn. 40). In the Latin American and Caribbean region paid maternity leaves are as following: Argentina (13 weeks), Belize (14 weeks), Bolivia (13 weeks), Brazil (17 weeks), Chile (18 weeks), Colombia (18 weeks), Costa Rica (17 weeks), Cuba (18 weeks), Ecuador (12 weeks), El Salvador (16 weeks), Guatemala (12 weeks), Guyana (13 weeks), Haiti (12 weeks), Honduras (12 weeks), Jamaica (8 weeks), Nicaragua (12 weeks), Panama (14 weeks), Paraguay (18 weeks), Peru (14 weeks), Dominican Republic (14 weeks), Suriname (16 weeks), Uruguay (13 weeks), Venezuela (26 weeks). Bilo, Ch.; Tebaldi, R., Maternidad y paternidad en el lugar de trabajo en América Latina y el Caribe - políticas para la licencia de maternidad y paternidad y apoyo a la lactancia materna, Centro Internacional de Políticas para el Crecimiento Inclusivo (IPC-IG) and UNICEF-Oficina Regional para América Latina y el Caribe, Brasilia, Panama City, 2020, p. 52 (the full report may be consulted here: https:// www.unicef.org/lac/media/13931/file/Maternidad_y_paternidad_en_el_lugar_de_ trabajo_en_ALC.pdf, 11/04/2020).

56 Some public institutions grant more extensive paternity labor rights to men in Mexico (for example, a few days leave after the child is born or the possibility of sharing certain types of obligations with the child's mother). However, as it is based on the internal regulations of these institutions, the protection of paternity rights is minimal.

57 The length of a paternity leave varies from two up to fourteen days in the Latin America and Caribbean region. The shortest paternity leave (two days long) is in: Argentina, Guatemala, and the Dominican Republic. A three-day-long paternity leave exists in Bolivia, El Salvador, Panama, and Uruguay. A five-day-long paternity leave exists in Brazil, Chile, Mexico, and Nicaragua. A seven-day-long paternity leave exists in The Bahamas. An eight-day-long paternity leave exists in Colombia and Suriname. A ten-day-long paternity leave exists in Ecuador and Peru. The longest one (fourteen days long) is in Paraguay and Venezuela. It is also worth mentioning that only in Chile, Colombia, and Venezuela is the salary during the paternity leave paid by the state (social insurer), while in all the other countries 
of parental leave in the Mexican legal order (without any other possibility of transferring any part of the maternity leave to a child's father). ${ }^{58}$ Even though, at first sight, paternity rights (especially paternity leave) do not seem like a necessary tool for improving women's position in the labor market, it is quite the opposite. Furthermore, parental leave would allow equaling, at least to a certain extent, women's and men's position at work vis-a-vis parenthood. Finally, it must also be realized that maternity leaves are not everything; the relationship between maternity and its impact on the professional development of women is so great that the maternity protection regime must be seen from a much wider and holistic perspective. ${ }^{59}$

\section{CONCLUSIONS: MISSION TO MARS}

As may be derived from the presented analysis, women are victims of gender discrimination all around the world, and one of its faces is discrimination in the labor market (directly related to the reproductive work and role they have). As it was demonstrated in this article, women suffer even greater gender discrimination in the labor market once they become mothers, and the gender pay gap increases then even more. An explanation for this phenomenon may be found in the psychological and economic theories on discrimination, as presented above. Thus, to diminish (and eventually eradicate) the problem of labor gender discrimination, the international community has developed various international legal instruments and actively encourages states to implement appropriate national legislation targeting discrimination. Balancing the position of women and men not only in the labor market but also in society requires the legal and factual possibility of exercising child-related rights and obligations on equal terms.

In the case of Mexico, where only one parent (the mother) can enjoy leave due to becoming a parent (in the form of maternity leave), even though, in theory, it

the salaries must be paid by the employers. In the case of The Bahamas, paternity leave is unpaid. Ibid. Calderón Unda, A. E., Licencias parentales: análisis del permiso de paternidad en México y el permiso postnatal parental en Chile, Revista Latinoamericana de Política Comparada, No. 15, 2019, pp. 40-41.

58 The institution of parental leave is not common in the Latin American and Caribbean regions. To date, a fully paid parental leave of twelve weeks exists only in Chile. In some forms, parental leave can also be taken in Cuba (60\% of the salary is paid), Ecuador (50\% of the salary is paid), and Ecuador (unpaid). Bilo, Tebaldi, op. cit. (fn. 55).

59 Moolman, J., Talking about Maternity Benefits, Agenda: Empowering Women for Gender Equity, No. 35, 1997, p. 73. 
grants her additional protection, it also prevents the further involvement of the father in the process of the child's upbringing (a five-day-long paternity leave does not make a significant impact). Therefore, the full system, as derived from the Mexican Constitution ${ }^{60}$ and the Federal Labor Law, requires substantial amendments to: 1) boost the level of protection for women especially by: a) increasing the maternity leave from twelve weeks up to a minimum of fourteen weeks (as this is the minimum period currently recommended by the ILO); and b) increase the length of the breastfeeding-entitlement period from six months up to a minimum two years (as previously mentioned, the WHO recommends breastfeeding up to two years - which is not possible without appropriate legal regulations); 2) grant more paternal rights to men especially by increasing the paternity leave from five days up to fourteen days (as to allow a father to actively contribute to the child's and house-related chores, as well as to take care of the mother especially in the crucial post-natal period); and 3) introduce an institution of parental leave of twelve weeks. ${ }^{61}$ It must also be underlined that all the aforementioned leaves (maternity, paternity, and parental) should be fully paid as in the majority of cases fathers earn more than the mothers (stemming from the gender pay gap, as discussed above), so providing only a certain percentage of a salary especially during the paternity or parental leave discourages a multitude of fathers (and families) from taking this option. ${ }^{62}$ Only then will women's reproductive work be able to coexist with a productive, professional one, which consequently will diminish gender labor discrimination and the

60 Due to a strong tendency of constitutionalizing the majority of significant regulations in Mexico, the inclusion of paternity and parental leaves in the Mexican Constitution is also proposed. Rivera, M. A., Understanding Constitutional Amendments in Mexico: Perpetuum Mobile Constitution, Mexican Law Review, vol. IX, no. 2, 2017, p. 23.

${ }_{61}$ One example of progressive legislation in the American region is Chile, where a law granting a twelve-weeks-long parental leave (to be taken by any of the parents) was passed in 2011. Casas, L.; Herrera, T., Maternity protection vs. maternity rights for working women in Chile: Historical Review, Reproductive Health Matters, vol. 20, no. 40, 2012, p. 144.

62 Institute of Employment Rights Journal, Equality at work, vol. 3, 2020, p. 81. 
pay gap. ${ }^{63}$ Moreover, men must be encouraged to use family-friendly policies. ${ }^{64}$ Finally, a linguistic shift from "protection" of maternity and mothers' rights to "promotion" is necessary as it will aid in dismissing arguments according to which a mothers' work is simply too costly for employers due to all the maternity-related "benefits".

As may be garnered from the analysis presented in this article, the full eradication of gender labor discrimination still remains a mission to Mars. We all know that Mars exists; we also want to conquer it; however, the possibility of doing so remains very distant. Hopefully, within the next few years, by the mutual efforts of the international community and national legislators, the involvement of society, governmental and non-governmental organizations, it will be at least possible to diminish and eventually eradicate gender labor discrimination, so that, no longer, will maternity be considered a "social risk". ${ }^{65}$

63 The solutions applied in Scandinavian countries (especially Sweden and Norway) such as gender-neutral parental leaves with symmetrical rights (meaning that a part of the leave is reserved for the mother, an equal amount of time for the father and the rest of the time may be divided between both according to their preferences) must be considered examples of good practices and legislation on a worldwide scale. It must also be noted that the Scandinavian models of parenthood protection are partially based on EU directives, such as: the Council Directive 92/85/EEC of 19 October 1992 on the introduction of measures to encourage improvements in the safety and health at work of pregnant workers and workers who have recently given birth or are breastfeeding and Directive (EU) 2019/1158 of the European Parliament and of the Council of 20 June 2019 on the work-life balance for parents and carers (repealing Council Directive 2010/18/EU). Grönlund, A.; Halldén, K.; Magnusson, Ch., A Scandinavian success story? Women's labor market outcomes in Denmark, Finland, Norway and Sweden, Acta Sociologica, vol. 60, no. 2, 2017, p. 101. See also The European Foundation for the Improvement of Living and Working Conditions, The EU parental leave agreement and Directive: implications for national law and practice, 1998, https://www.eurofound.europa.eu/publications/report/1998/the-euparental-leave-agreement-and-directive-implications-for-national-law-and-practice (11/04/2021).

64 Therefore, some scholars argue that policies focusing on cultural changes are necessary to reduce the occupational inequality. Haveman, H. A.; Beresford, L. S., If you're so smart, why aren't you the boss? Explaining the persistent vertical gender gap in management, The Annals of the American Academy of Political and Social Science, vol. 639, 2012, pp. 114-130.

65 As indicated in the ILO Social Security Convention (no. 102) of 1952. Boswell, Boswell, B., op. cit. (fn. 40). 


\section{BIBLIOGRAPHY}

Adams, R.; Funk, P., Beyond the Glass Ceiling: Does Gender Matter?, Management Science, vol. 58, no. 2, 2012, pp. 219-235.

Al Ramiah, A.; Hewstone, M.; Dovidio, J. F.; Pennerp, L. A., The Social Psychology of Discrimination: Theory, Measurement, and Consequences, in: Russell, H.; Bond L.; McGinnity, F. (eds.), Making equality count: Irish and international approaches to measuring discrimination, Liffey Press, Dublin, 2010, pp. 84-112.

Arrow, K., The Theory of Discrimination, in: Aschenfelter, O.; Rees, A. (eds.), Discrimination in Labor Markets, Princeton University Press, Princeton, 1973, pp. 3-33.

Bertrand, M., The Glass Ceiling, Becker Friedman Institute for Economics at the University of Chicago, Working Paper, No. 38, 2018, pp. 219-236.

Bilo, Ch.; Tebaldi, R., Maternidad y paternidad en el lugar de trabajo en América Latina y el Caribe-políticas para la licencia de maternidad y paternidad y apoyo a la lactancia materna, Centro Internacional de Políticas para el Crecimiento Inclusivo (IPC-IG) and UNICEF-Oficina Regional para América Latina y el Caribe, Brasilia, Panama City, 2020.

Boswell, R.; Boswell, B., Motherhood deterred: Access to maternity benefits in South Africa, Agenda: Empowering Women for Gender Equity, no. 82, 2009, pp. 76-85.

Budig, M.; Misra, J.; Boeckmann, I., The Motherhood Penalty in Cross-National Perspective: The Importance of Work-Family Policies and Cultural Attitudes, Social Politics, vol. 19, no. 2, 2012, pp. 163-193.

Calderón Unda, A. E., Licencias parentales: análisis del permiso de paternidad en México y el permiso postnatal parental en Chile, Revista Latinoamericana de Política Comparada, no. 15, 2019, pp. 31-53.

Casas, L.; Herrera, T., Maternity protection vs. maternity rights for working women in Chile: Historical Review, Reproductive Health Matters, vol. 20, no. 40, 2012, pp. 139-147.

Correll, J.; Judd, C. M.; Park, B.; Wittenbrink, B., Measuring prejudice, stereotypes and discrimination, in: Dovidio, J. F.; Hewstone, M.; Glick, P.; Esses, V. M. (eds.), The Sage Handbook of Prejudice, Stereotyping, and Discrimination, SAGE Publications Ltd., London, 2010, pp. 45-62.

Correll, Sh. J.; Benard, S.; Paik, I., Getting a Job: Is There a Motherhood Penalty?, American Journal of Sociology, vol. 112, no. 5, 2007, pp. 1297-1338.

Eisner, S. P., The Mommy Trek? Working Women's Choices, Journal of Diversity Management, vol. 2, no. 1, 2007, pp. 1-16. 
Grönlund, A.; Halldén, K.; Magnusson, Ch., A Scandinavian success story? Women's labor market outcomes in Denmark, Finland, Norway and Sweden, Acta Sociologica, vol. 60, no. 2, 2017, pp. 97-119.

Guryan, J.; Charles, K. K., Taste-Based or Statistical Discrimination: The Economics of Discrimination Returns to its Roots, The Economic Journal, vol. 123, no. 572, 2013, pp. F417-F432.

Haveman, H. A.; Beresford, L. S., If you're so smart, why aren't you the boss? Explaining the persistent vertical gender gap in management, The Annals of the American Academy of Political and Social Science, vol. 639, 2012, pp. 114-130.

Hill, E.; Hawkins, A.; Ferris, M.; Weitzman, M., Finding an Extra Day a Week: The Positive Influence of Perceived Job Flexibility on Work and Family Life Balance, Family Relations, vol. 50, no. 1, 2001, pp. 49-58.

Instituto Mexicano para la Competitividad, Las mujeres no ganan lo mismo que los hombres. Análisis de la brecha salarial en México, Mexico City, 2020.

Instituto Nacional de las Mujeres, Brecha salarial de género en México, Año 2016II, Mexico City, 2016.

Kingson, J. A., Women in the Law Say Path Is Limited by 'Mommy Track', The New York Times, August 8, 1988, Section A, p. I.

Lambert, C., Reproducing Discrimination: Promoting the Equal Sharing of Caring Work in CEDAW, at the ILO and in the SDA, in: Thornton, M. (ed.), Sex Discrimination in Uncertain Times, Australian National University, Canberra, 2010, pp. 153-157.

Lindbolm, T., Article 1, in: Alfredsson, G.; Eide, A. (eds.), The Universal Declaration of Human Rights: A Common Standard of Achievement, Martinus Nijhoff Publishers, The Hague/Boston/London, 1999, pp. 41-47.

Moolman, J., Talking about Maternity Benefits, Agenda: Empowering Women for Gender Equity, no. 35, 1997, pp. 73-75.

Phelps, E. S., The Statistical Theory of Racism and Sexism, American Economic Review, vol. 62, 1972, pp. 659-661.

Półtorak, M., Projekt Dyrektywy WLB-Nowe podejście do równości płci w zatrudnieniu?, Studia z Zakresu Prawa Pracy i Polityki Społecznej, no. 4, 2019, pp. 317-339.

Radcliffe Richards, J. M.; Lucas, J. R., Discrimination, Proceedings of the Aristotelian Society, Supplementary Volumes, vol. 59, Oxford University Press, 1985, pp. 53-83.

Rivera, M. A., Understanding Constitutional Amendments in Mexico: Perpetuum Mobile Constitution, Mexican Law Review, vol. IX, no. 2, 2017, pp. 3-27.

Rzecznik Praw Obywatelskich, Przeciw dyskryminacji: Poradnik RPO, Biuro Rzecznika Praw Obywatelskich, Warszawa, 2013. 
Schwartz, F., Management Women and the New Facts of Life, Harvard Business Review, January 1, 1989.

Stewart, J., The Mommy Track: The Consequences of Gender Ideology and Aspirations on Age at First Motherhood, Journal of Sociology \& Social Welfare, vol. 30, no. 2, 2003, pp. 3-30.

Vogel, L., ILO New Maternity Convention (2000), Women, Work and Health, 2000, pp. 9-11. 
Sažetak

\section{Barbara Stepień*}

\section{MAJKE I ŽENE KOJE NISU MAJKE NA TRŽIŠTU RADA: UREĐENJE U MEKSIKU NASUPROT KONVENCIJI MOR-a O ZAŠTITI MAJČINSTVA, 2000. (BR. 183)}

Cilj je rada analizirati društveni i pravni položaj žena na tržištu rada, posebno u vezi s utjecajem koji na to ima majčinstvo. U prvom dijelu rada namjera je autorice upotrebom psiholoških i ekonomskih teorija o diskriminaciji pojasniti razloge zašto su žene diskriminirane na tržištu rada nakon što postanu majke. Središnji dio donosi detaljnu analizu i raspravu o zabrani diskriminacije $i$ zaštiti majčinstva u međunarodnim okvirima, u prvom redu u vezi s Konvencijom MOR-a o zaštiti majčinstva, 2000. (br. 183), te zatim zakonodavno uređenje u Meksiku. Autorica zaključno predlaže uvođenje i razvoj radnopravne zaštite $i$ očeva (očinstva) kao nužni preduvjet brisanja spolne diskriminacije na tržištu rada.

Ključne riječi: spol, diskriminacija, pay gap, majčinstvo, očinstvo, prava iz radnog odnosa

* Dr. sc. Barbara Stępień, profesorica, Universidad Iberoamericana, Prolongacion Paseo de la Reforma 880, Lomas de Santa Fe, Álvaro Obregón, 01219 Mexico City, Meksiko; barbara.stepien@hotmail.com;

ORCID ID: orcid.org/0000-0002-2430-5445 